\title{
Silvofishery Pond: An Alternative to Disaster Mitigation Efforts
}

\author{
Meilinda Suriani Harefa ${ }^{1}$, Zulkifli Nasution ${ }^{2}$, Miswar Budi Mulya ${ }^{3}$, Azhar Maksum ${ }^{4}$ \\ \{meilindasuriani@unimed.ac.id¹, zulnasution@usu.ac.id², miswarbm_ikl@yahoo.com³ \\ azharmaksum16@gmail.com $\left.{ }^{4}\right\}$ \\ Universitas Sumatera Utara, North Sumatera, Indonesia
}

\begin{abstract}
This study aims to determine the background of the community practiced silvofishery pond model to mitigate disaster in Tanjungrejo village, district of Percut Sei Tuan, Deli Serdang regency. This research was conducted with a questionnaire tool, interviews and field observations of 22 informants who have good pond infrastructure and have been practicing silvofishery pond model for 5 years. This research uses the descriptive method with a qualitative approach. The results showed that all of the questions asked to farmers, there were 10 statements that were submitted and 4 of them were the most frequent statements that could be a conclusion about the background of the fish-farmer practised silvofishery pond model, including percentage of mangrove in the pond, affects noncultivation production during the high tide $(95 \%)$, total area of mangrove stands has a positive impact on the activity of crab enlargement in the pond (91\%), maintaining the presence of mangroves around the pond can better affect fisheries production $(91 \%)$, and the number of stands mangroves in ponds can prevent damage from wave blows (86\%). As the factors that indicate silvofishery pond model as one of disaster mitigation efforts is the continuity of the mangrove function as an instrument to protect the land from erosion and abrasion, the presence of mangroves on the pond can reduce and absorb strong winds from the sea and as a producer of organic materials that support the food chain.
\end{abstract}

Keywords: silvofishery, pond, disaster, mitigation

\section{Introduction}

The mangrove forest is a complex and unique ecosystem and has a large enough supporting capacity for the surrounding environment because it has high productivity and benefits, especially from its ecological and economic functions, both directly and indirectly. Mangrove also has a special ability to adapt to extreme environmental conditions, such as stagnant soil conditions, high salinity, and unstable soil conditions. Besides its benefits in supporting coastal life, the destruction rate of mangrove forests in Indonesia continues to grow from year to year, causing natural disasters frequently occur in coastal areas. The destruction of mangrove forests is closely related to land use patterns to meet the economic needs of the community. The livelihoods of the population living in the mangrove ecosystem are highly dependent on the presence of mangrove forest and fisheries resources [1]. However, the loss of mangroves since the 1960s-1970s had already 
occurred, where the community opened the mangrove forests for the expansion of settlements and intensive pond farming, the transition of mangrove forests into oil palm plantations and other uses.

In the 1990s, Indonesia enhanced shrimp production on a large scale by opening mangrove forests into intensive shrimp ponds model with the expectation for gaining high profits without realized this activity caused a significant impact on the loss of mangrove forests [2]. Forest destruction also occurred in Tanjungrejo village, district of Percut Sei Tuan, Deli Serdang regency that caused by opening an intensive pond model for shrimp cultivation. But, lately intensive pond model has abandoned because losing mangroves have a bad impact on community life. The significant loss of mangroves certainly affecting land damage and has caused disasters as they experienced before. Intensive fish farmers have gradually shifted to conservative pond management named silvofishery pond model, which is a pond management model by combining and maintaining fishery cultivation with mangrove stands to mitigate negative impacts of the environment [3].

\section{Research method}

This research was conducted in Tanjungrejo village, Percut Sei Tuan, Deli Serdang regency in July-August 2019. Tanjungrejo is one of the villages in the coastal area of North Sumatra where the livelihoods of its people are farmers of silvofishery pond. The population in this study was farmers of silvofishery pond in Tanjungrejo village, district of Percut Sei, Deli Serdang regency. The sampling technique is using a purposive sampling method for 22 fish-farmers. The selected fish-farmers has been practicing the concept of the silvofishery pond model for approximately 5 years with a good pond infrastructure and natural harvesting system at full tide session. Respondent data can be seen in Table 1 below.

Table 1. The data of respondents

\begin{tabular}{cccccc}
\hline $\begin{array}{c}\text { Number } \\
\text { of ponds }\end{array}$ & $\begin{array}{c}\text { Large of ponds } \\
\text { (hectare) }\end{array}$ & \multicolumn{2}{c}{ large (ha) } & \multicolumn{2}{c}{ percentage (\%) } \\
mangrove & pond & mangrove & pond \\
\hline 1 & 1,9 & 1,49 & 0,41 & 78,42 & 21,58 \\
2 & 7,81 & 6,33 & 1,48 & 81,05 & 18,95 \\
3 & 2,43 & 1,95 & 0,48 & 80,25 & 22,75 \\
4 & 2,4 & 1,87 & 0,53 & 77,92 & 33,66 \\
5 & 4,1 & 2,72 & 1,38 & 66,34 & 34,27 \\
6 & 4,64 & 3,05 & 1,59 & 65,73 & 63,22 \\
7 & 1,74 & 0,64 & 1,1 & 36,78 & 47,21 \\
8 & 6,1 & 3,22 & 2,88 & 52,79 & 55,30 \\
9 & 1,15 & 0,56 & 0,59 & 48,70 & 55,30 \\
10 & 7,22 & 3,24 & 3,98 & 44,88 & 56,90 \\
11 & 4,72 & 2,11 & 2,61 & 44,70 & 59,26 \\
12 & 8,4 & 3,62 & 4,78 & 43,10 & 59,93 \\
13 & 1,62 & 0,66 & 0,96 & 40,74 & 62,56 \\
14 & 8,51 & 3,41 & 5,1 & 40,07 & 72,04 \\
15 & 2,19 & 0,82 & 1,37 & 37,44 & 73,47 \\
16 & 2,11 & 0,59 & 1,52 & 27,96 &
\end{tabular}




\begin{tabular}{lccccc}
18 & 12,4 & 3,5 & 8,9 & 28,23 & 71,77 \\
19 & 4,35 & 0,93 & 3,42 & 21,38 & 78,62 \\
21 & 1,36 & 0,26 & 1,1 & 19,12 & 80,88 \\
20 & 3,87 & 0,55 & 3,32 & 14,21 & 85,79 \\
22 & 5,1 & 0,78 & 4,32 & 15,29 & 84,71 \\
\hline
\end{tabular}

Data collection techniques with observation carried out directly in the location of the study, then distributed questionnaires and open interviews. After the open interview, all answers from respondent are collected and divided into 5 percentage classes, that is $0 \%<20 \%$ is very small, 21 $\%-40 \%$ is small; $41 \%-60 \%$ is medium, $61 \%-80 \%$ is high, and $81 \%-100 \%$ is very high. After the open interview, it was continued with an in-depth discussion to analyze the role of the silvofishery pond model as an economic activity and its ability to prevent disasters. All data that obtained then were analyzed using descriptive analysis.

\section{Results And Discussion}

The result from in-depth interviews with owner silvofishery pons in Tanjungrejo village, District of Percut Sei Tuan obtained 10 statements that were often mentioned and became the reasons for the fish-farmers practicing silvofishery pond model. See Table 2 below.

Table 2. Reasons for fish-farmers practicing silvofishery pond models

\begin{tabular}{|c|c|c|c|}
\hline \multirow[t]{2}{*}{ no } & \multirow[t]{2}{*}{ type of the statements } & \multicolumn{2}{|c|}{ statements } \\
\hline & & $\begin{array}{l}\text { number of } \\
\text { respondents }\end{array}$ & $\begin{array}{c}\text { percentage } \\
(\%)\end{array}$ \\
\hline 1 & $\begin{array}{l}\text { The total area of mangrove stands has a positive impact on } \\
\text { the activity of crab enlargement in the pond. }\end{array}$ & 20 & 91 \\
\hline 2 & $\begin{array}{l}\text { The presence of mangrove trees can reduce the cost of } \\
\text { maintaining the fishery cultivation. }\end{array}$ & 15 & 68 \\
\hline 3 & $\begin{array}{l}\text { Maintaining the presence of mangroves around ponds can } \\
\text { cause better fishery cultivation. }\end{array}$ & 20 & 91 \\
\hline 4 & $\begin{array}{l}\text { The percentage of mangroves in a pond affects the } \\
\text { production of non-cultivation fish that comes at high tide } \\
\text { session. }\end{array}$ & 21 & 95 \\
\hline 5 & $\begin{array}{l}\text { The utilization of mangrove wood from ponds for } \\
\text { household needs is another advantage obtained by } \\
\text { silvofishery fish-farmers }\end{array}$ & 14 & 64 \\
\hline 6 & $\begin{array}{l}\text { The presence of mangrove stand that grows well around } \\
\text { pond contributes to the production when the high tides } \\
\text { occur }\end{array}$ & 15 & 68 \\
\hline 7 & $\begin{array}{l}\text { Mangrove stand in the pond prevents damage from the } \\
\text { waves }\end{array}$ & 19 & 86 \\
\hline 8 & $\begin{array}{l}\text { The presence of mangroves in ponds and surrounding areas } \\
\text { affects water temperature which supporting the fish } \\
\text { production }\end{array}$ & 15 & 68 \\
\hline
\end{tabular}


9 The existence of mangrove stand in the pond can prevent pollution of water entering the area around the pond

10 The existence of mangroves in the pond and around can maintain the quality of the water that enters the pond

Based on table 2 the grouping of percentage class ranges obtained 4 very high statements as reasons for fish-farmers practised a silvofishery pond model: percentage of mangroves in the pond affects the results of non-cultivation production that enter the tide (95\%), The total area mangrove stands have a positive impact on the activity of crab enlargement in the pond $(91 \%)$, The number of mangrove stands around the pond can affect more fishery production $(91 \%)$ and the number of mangrove stands in the pond can prevent damage from wave blows (86\%). By the in-depth interviews with the fish-farmer, the factors that caused silvofishery pond model was selected as an option in efforts to mitigate disasters, including: (1) the continuity of the function of mangrove forests as a support for fisheries production, (2) the presence of mangrove stands in the pond can act as a protector from erosion and abrasion in the mangrove ecosystem area, (3) reducing or absorbing strong winds from sea to land, and (4) producing organic materials that support the food chain.

The reasons for fish-farmers practicing silvofishery pond models are: (1) the percentage of mangroves in the ponds affects the production of the non-cultivation fishery that entered at high tide.

From the experience of fish-farmers was obtained that the presence of mangrove stands which grown and maintained in the pond gives a very high contribution to the productivity of noncultivation fisheries through nets placed at the Watergate. The fishery yield was obtained very promising to meet the farmer's economy. At high tide, for about a week the results of catching fish and shrimp can be sold for IDR 750,000 to IDR 1,500,000. The mangroves that grow well in ponds will affect the production of non-cultivation fishes that come at high tide and through the Watergate [4]. This is due to the covering of mangroves that will produce a lot of nutrients as a food source for fish and shrimp, thus attracting shrimp and fish coming from outside into the pond. This condition is very beneficial for fish farmers, in addition to waiting the harvest time from cultivation about 6 months per cycle, they also harvest from non-cultivation that has economic value. The mangrove cover contributes significantly to the daily catch of shrimp from outside the pond that entered the pond through the tide flow [5].

Furthermore, (2) the number of mangrove stand has a positive impact on the activity of crab enlargement in the pond silvofishery fish-farmers in Tanjungrejo village conduct cultivation activities depending on the percentage of mangrove cover in the pond. The more width mangroves in the pond, the percentage of crab harvest is greater than the number of fish cultivation. The type of crab that is raised and cultivated is the type of mangrove crab (Scylla Serrata) also known as mud crab, including the class Crustacea, Order Decapoda, family Portunidae, and genus Scylla. Mangrove crabs take shelter, find food and grow on mangrove roots. Mangrove crabs are usually found at the bottom of the sandy mud at the coastline or river banks [6].

Based on the results of the study, it was found that mangrove crabs grow faster and spawn eggs when maintained by intercropping with mangroves if compared to ponds without mangroves [7]. Mangrove crabs depend on mangroves and where this condition can be created in a silvofishery pond model. Specifically, for male mangrove crabs, mangrove stands to act as a safe food supply 
and protector from sea waves. Mangrove crabs prefer to move by crawling rather than swimming to move and find food and use mangrove roots as a medium to make it easier to move [8]. Furthermore, (3) the existence of mangroves around ponds can affect a better fishery cultivation production. In the silvofishery ponds model the production is expected to be divided into 2 parts: (1) harvests from fish that are cultivated and have a fixed maintenance cycle; (2) harvest from non-cultivation that incoming by ocean currents at high tide. Silvofishery pond model provides space for mangrove growth and the role of mangroves can support fish farming activities with a silvofishery system [9]. Furthermore, the optimum conditions for fisheries production with a culture system in silvofishery ponds were mangrove cover areas between $40-60 \%$ of the pond area. Silvofishery production is positively correlated with the presence of mangrove ecosystems adjacent to the area of cultivation activities [10].

Finally, (4) the number of mangrove stand in the pond can prevent damage from the waves. In the practice of pond management, one of the concerns is the coming of high wave currents to hit the pond walls and break the embarkment. The presence of mangrove stands that grow in and around the pond can reduce the incoming water waves when the tide comes. Mangrove tree roots embedded in the soil will strengthen the pond, so it is not easily broken by waves or lifts the sediment. The function of mangroves in the pond acts as a wind and wave breaker to prevent abrasion and erosion in the pond and its surroundings [11].

The factors that cause silvofishery model ponds as options in efforts to mitigate disaster is (1) sustainability of the function of mangrove forests. Silvofishery pond model is pond management systems by combining mangrove stands and fisheries cultivation that is applied in the mangrove ecosystem area. This model can reduce the loss of mangrove stands because mangroves that grow in ponds and around ponds can carry out their ecological and economic functions. Ecological and economic functions together contribute to the mitigation of disasters in Tanjungrejo village. The following information from fish farmers that the previous condition was the tide entered the land (settlement) because there is no natural barrier that can hold water around the pond. Some ponds that are managed in an intensive model are destroyed and cannot be re-functioned because the embankment is destroyed by the tidal water entering the pond. Likewise, the feed for cultivation in ponds requires a large cost because mangroves as a supplier of natural food have been cut down.

Learning from the losses that fish farmers have previously experienced from intensive farm management models, farmers have realized that mangrove stand in ponds and around ponds can also function to provide nutrients and pollutant absorbent so that they can neutralize waste in ponds and at the same time be able to increase pond productivity [12]. Furthermore, (2) protecting from erosion and abrasion in mangrove ecosystem areas. Mangrove trees have a distinctive root system in the form of pneumatic for and knee roots that can hold water and waves. Mangrove stands in and around silvofishery ponds can trap and strengthen the soil sediments when currents occur from the sea so the land is protected from erosion and abrasion. If erosion and abrasion continue, absolutely land will get smaller and sea level water will increase. The silvofishery pond model could protect the pond from negative effects such as erosion and abrasion caused by rising sea levels [13].

The next factor (3), absorbing the winds from sea to land. A dense mangrove canopy can be a barrier to the sea breeze so that the area around the mangrove stands is protected from wind damage. The ability of mangroves to reduce wind can affect the microclimate in the pond area because the material on land is very vulnerable to damage by high wind speeds and the 
consequences of such damage are natural disasters. If there are sea wind blockers such as mangrove stands then the risk of direct disaster caused by the wind can be avoided [14]. Finally, (4) producing organic material that supports the food chain. Maintaining the existence of mangroves not only increases economic benefits but also increases the biodiversity of flora and fauna in it as a supply of organic material. This opinion is reinforced that mangroves play an important role in the life cycle of various species of fish, shrimp, and mollusks because mangroves can provide food in the form of organic materials that enter the food chain [15]. Furthermore, one of the objectives of implementing silvofishery model ponds is to create a balanced ecosystem, so that in terms of ecology and economy, mangrove ecosystems can function optimally and sustainably which certainly contributes to disaster mitigation.

\section{Conclusion}

Based on information from fish farmers in Tanjungrejo village, district of Percut Sei, Deli Serdang regency who used to manage the ponds with an intensive model, then currently choose a silvofishery pond model with the main reason being that the percentage of mangrove in the pond affects non-cultivation yields that entered the during the high tide, the number of mangrove stands has a positive impact on the activity of crab enlargement in the pond, the presence of mangroves around the pond can affect better cultivation production and mangrove stands in the pond can prevent damage from the sea waves.

Furthermore, the factors supporting the silvofishery pond model become conservative economic activity as an effort to mitigate disasters due to the continuity function of the mangrove forest in the pond to support fisheries production, protect against erosion and abrasion, can absorb strong winds from the sea to land and as producer of organic material that supports the food chain. This research can be continued by measuring the contribution of the physical mangrove area in the pond to cultivation and non-cultivation production to provide an overview of the economic value of mangroves and the value of disaster mitigation.

\section{References}

[1] M. Basyuni, P. Yani, and K. S. Hartini, "Evaluation of mangrove management through communitybased silvofishery in North Sumatra, Indonesia," in IOP Conference Series: Earth and Environmental Science, 2018.

[2] M. Suriani Harefa, M. S. Harefa, Z. Nasution, M. B. Mulya, and A. Maksum, "The Effort to Maintain Mangrove Forest through the Development of Sylvofishery Pond," in Proceedings of the 1st International Conference on Social Sciences and Interdisciplinary Studies (ICSSIS 2018), 2019.

[3] K. Wibowo and T. Handayani, "Pelestarian Hutan Mangrove Melalui Pendekatan Mina Hutan (Sylvofishery),” J. Tek. Lingkung., 2006.

[4] Y. Suryaperdana, K. Soewardi, and A. Masha, "Keterkaitan Lingkungan Mangrove pada Produksi Udang dan Ikan Bandeng Di Kawasan Sylvofishery Blanakan, Subang, Jawa Barat," Bonorowo Wetl. 274 , vol. 85, 2012.

[5] Y. Amrial, H. Effendi, and A. Damar, "Pengelolaan Ekosistem Mangrove Berbasis Sylvofishery di Kecamatan Cibuaya, Kabupaten Karawang,” J. Kebijak. Sosek Kelaut. Perikan., 2015.

[6] M. Suryani, "Ekologi kepiting bakau (Scylla Serrata Forskal) Dalam ekosistem mangrove di Pulau 
Enggano Provinsi Bengkulu," program Pascasarjana Universitas Diponegoro, 2006.

[7] Irwani and C. A. Suryono, "Pertumbuhan Kepiting Bakau Scylla Serrata di Kawasan Mangrove," Bul. Oseanografi Mar. 2012.

[8] N. I. Wijaya and F. Yulianda, "BIOLOGI POPULASI KEPITING BAKAU (Scylla Serrata F.) DI HABITAT MANGROVE TAMAN NASIONAL KUTAI KABUPATEN KUTAI TIMUR oleh," 2010.

[9] R. Budihastuti, "Pengaruh Penerapan Wanamina Terhadap Kualitas Lingkungan Tambak dan Pertumbuhan Udang di Kota Semarang," Pros. Semin. Nas. Pengelolaan Sumber. Alam dan Lingkung., 2013.

[10] A. Haris, A. Damar, D. Bengen, F. Yulianda, and others, "Correlation between mangrove and aquaculture production: a case study in Sinjai District, Sulawesi, Indonesia," Int. J. Aquac., vol. 3, 2013.

[11] A. H. Sambu and I. Sribianti, "The management of mangrove ecosystem based on mitigation: a case study in the mangrove area of Tongke-tongke, South Sulawesi," Int. J. Ocean. Oceanogr., vol. 10, no. 1, pp. 61-71, 2016.

[12] E. D. Hastuti and R. Budihastuti, "Potential of mangrove seedlings for utilization in the maintenance of environmental quality within silvofishery ponds," Biotropica (Bogor)., 2016.

[13] W. P. Wijayanti and R. A. Pratomo, "Adaptation of Social-economic Livelihoods in Coastal Community: The Case of Mangunharjo Sub-District, Semarang City," Procedia-Social Behav. Sci., vol. 227, pp. 477-484, 2016.

[14] B. Clough et al., "Sylvofishery Farming Systems in Ca Mau Province, Vietnam," 2002.

[15] S. S. S. Subekti, "PERAN MANGROVE SEBAGAI KETERSEDIAAN MATERI PANGAN," Pros. SNST Fak. Tek., vol. 1, no. 1, 2012. 